\title{
Introduction of microscopic non-indigenous species through ballast water in Arzew Gulf (SW Mediterranean Sea): the case of the harmful raphidophyceae Fibrocapsa japonica S.Toriumi et H.Takano, 1973 (Chattonellaceae)
}

\author{
Ali Lamia' Bachari Nour El Islam', Mokrane Zakia² \& Chala Ania' \\ ${ }^{1} 1$ USTHB/ University of Science and Technology Houari Boumediene - Laboratory of Spatial Oceanography- $\mathrm{N}^{\circ} 32$ \\ El-Alia, Bab Ezzouar 16111, Algiers, Algeria \\ ${ }^{2}$ CNRDPA/National Center for Research and Development of Fisheries and Aquaculture, 11 Boulevard Amirouche, \\ Bou-Ismail, Tipaza, Algeria \\ Corresponding author: ali-lamia@hotmail.com
}

\begin{abstract}
The transfer of non-indigenous species (NIS) into the marine environment is mainly carried out by maritime transport (biofouling or ballast water). Ports are therefore the gateway to NIS, which can alter local biodiversity. In this study, the port of Arzew and Bethioua (Algeria, south-western Mediterranean) were studied for the presence of NIS by taking the case of the harmful Raphidophyceae Fibrocapsa japonica. Seawater samples were collected following a comparative sampling strategy between Arzew Gulf (AG region: presence of two hydrocarbon transport ports) and Ain Temouchent (AT region: absence of transport port - reference area). The Almeria-Oran front separates the two regions. The AT and AG regions generally have the same temperature, salinity and chlorophyll characteristics. The phtyhoplankton population showed a homogeneous quantitative distribution between the AT and AG regions. Diatoms and dinoflagellates have an equal density in both regions, nevertheless diatoms are more abundant in each region, (diatoms $6950 \mathrm{ind} / 1$ in AT $6380 \mathrm{ind} / 1$ in AG, dinoflagellates $1920 \mathrm{ind} / 1$ in AT and $1770 \mathrm{ind} / \mathrm{l}$ in AG). The specific assessment of the phytoplankton population revealed the presence of $F$. japonica at around $110 \mathrm{ind} / 1$ in the AG region in one station across the ports of Arzew and Bethioua and near the coast, and its absence in the reference area AT. Despite its presence in low density in a single station, this species remains harmful and presents a real danger if it is transported by the Algerian current along the coast to other places, in particular fisheries and aquaculture production areas. This study is part of a prevention process, is the first signaling of microscopic non-indigenous species on the Algerian coast, and contributes to establish a database for future assessments of microscopic NIS in Algerian ports.
\end{abstract}

KEY WORDS NIS; Arzew Gulf; ballast water; Fibrocapsa japonica; harmful algae.

\section{INTRODUCTION}

Since it was first reported in USA and Japan, the Raphidophyceae Fibrocapsa japonica (S.Toriumi et
H. Takano, 1973) has attracted the attention of several researchers and has been studied for its ecology and toxicity, which can cause fish kills (Iwasaki, 1971; Toriumi \& Takano, 1973; Okaichi, 
1989; Hiromi et al., 1995; Cortés-Lara et al., 2003; Vershinin \& Orlova, 2008; Härnström et al., 2009; Engesmo et al., 2018). Several mechanisms are responsible for this toxicity: production of brevetoxins, fatty acids and reactive oxygen species (ROS) (Khan et al., 1996a, b), an abundant production of mucous that clogs fish gills and the production of haemolytic compounds (Fu et al., 2004). At present, F. japonica has a wide geographical distribution (Fig. 1, Table 1) and is a typical temperate region species that cannot survive in Polar Regions (de Boer et al., 2005). Kooistra et al. (2001) suggest that anthropogenic activity (ship ballast water exchange and/or aquaculture) may have induced the expansion of the disjunct range of $F$. japonica. In addition, de Boer et al. (2005) concluded that the presence of $F$. japonica in the North Sea is of anthropogenic origin linked to ballast water exchange, as the physiology of strains observed in the North Sea is similar to the physiology of strains observed in the northern Pacific Ocean, although there is no direct contact between these waters.

In Alboran Sea (West Mediterranean basin), this species was detected for the first time in autumn 2006 by Fani et al. (2009). This basin covers the Algerian west coast where a study was carried out in our laboratory by Bouda et al. (2015) who estimated the risk of macroscopic species introduction by ballast water in the port of Arzew, with 76 donor ports of which 29 represent a high risk, 34 a medium risk and 13 a low risk. Previous work by researchers on $F$. japonica and the study of the risk of ballast water in Arzew gulf have led us to ask the following questions: can we validate the risk of introducing exotic species into Arzew gulf on a microscopic scale? Can we link the presence of $F$. japonica to ballast water?

The aim of our work is to respond to this problem in order to provide new data that could explain the processes of introduction of microscopic species in Algeria. Our study thus constitutes the first recording work of microscopic species introduced into Algerian waters, and could be a starting point for the realization of an inventory of introduced microscopic marine species in particular harmful phytoplankton. This study and the results of future related research will contribute to the enrichment of the first assessment of macroscopic species introduced into Algerian waters between 1834 and 2017 established by Grimes et al. (2018) and the first records of non-indigenous species in port of Arzew indicated by Bensari et al. (2020). All of this within a common prevention framework and to take "appropriate measures to regulate the in-

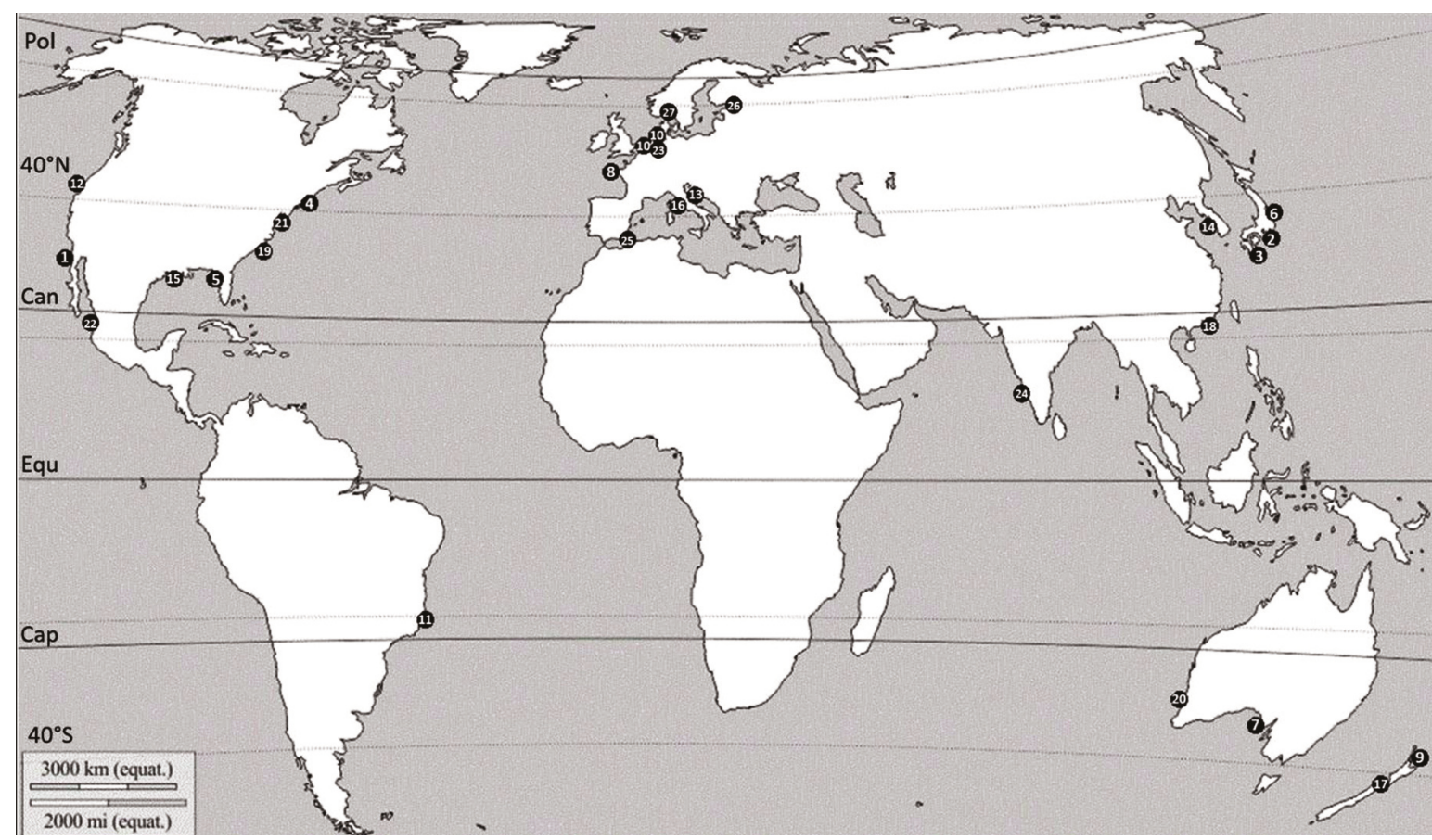

Figure 1. Distribution of Fibrocapsa japonica (modified from de Boer et al., 2004). 
tentional or accidental introduction of non-indigenous or genetically modified species into the wild and prohibit those that may have harmful impacts on the ecosystems, habitats or species", as required by the Barcelona Convention through its Protocol concerning specially protected areas and biological diversity (UNEP-MAP RAC/SPA, 2005), which were supported by Decision IG.22/12 related to "Species Introductions and Invasive Species" (UNEP/DEPI) /MED WG.421/26) (Grimes et al., 2018).

\section{MATERIAL AND METHODS}

\section{Study area}

In order to respond to the problems posed previously, our study is made in the geographical framework of Fani et al. (2014) and Bouda et al. (2015) work, namely the Algerian west coast. The ability to detect non-indigenous species (NIS), especially those of low abundance, is limited by the lack of data and information on phythoplankton species on the Algerian coast. Therefore we opted for a traditional method of detecting non-native species based on the comparison of two distinct regions of the western region (Fig. 2).

A distance of about $80 \mathrm{~km}$ separates the two areas, which corresponds to the geographical location of the Almeria-Oran front (Fig. 2). This front constitutes an ecological barrier that prevents the mixing of water bodies between the two zones. Several researchers in their recent studies in the region have used this sampling strategy (e.g., Diz \& Presa, 2008; García-Merchán et al., 2012; Riesgo et al., 2016; Pascual et al., 2017).

Arzew Gulf (AG): mainly chemical industries and large petrochemical slabs are present along the coast in the industrial poles of Arzew and Bethioua which are the main gateway for hydrocarbons exported from Algeria (Fig. 3). Most of ships berthing discharge systematically their ballast water. That is why the Regional Marine Pollution Emergency Response Centre for the Mediterranean Sea "REMPEC" report of 2008 classifies Arzew port among the most vulnerable ports, in the Mediterranean Sea, to such type of risk (Bouda et al., 2015).

Ain Temouchent (AT): this zone is essentially agricultural, bordered by tourist beaches and a single fishing port. There is no industrial activity and no ballast water discharge. For this reason this zone is considered a reference in our study.

\section{Sampling}

The study was based according to basic data collected during the prospecting campaign of the Algerian demersal resources "ALDEM 2017" conducted on July 2017 in partnership with the CNRDPA (National Center for Research and Development Fisheries and Aquaculture). Fourteen seawater samples were collected: 6 stations are located in Ain Temouchent and 8 stations are located in the Arzew Gulf (Fig. 3).

\section{Phytoplankton sampling and analysis}

Seawater samples were collected from surface

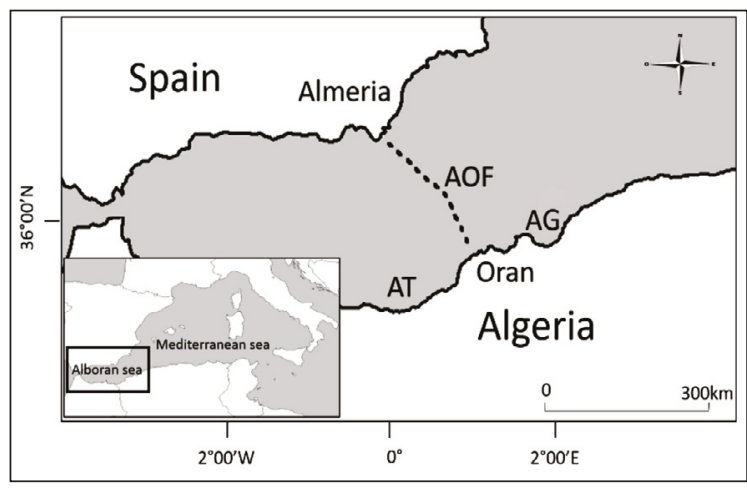

Figure 2. Sampling area in AG (Arzew Gulf); AT

(Ain Temouchent). AOF: Almeria Oran Front.

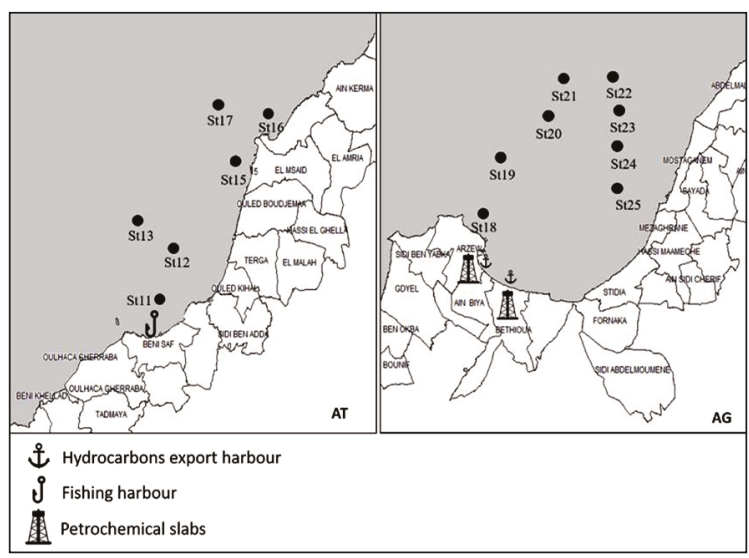

Figure 3. Sampling stations position AG (Arzew Gulf) and AT (Ain Temouchent). 
water using a 5L Niskin bottle mounted on a graduated rope. The sampled water was then transferred to a clean, dark polypropylene (PP) bottle with a volume of $1 \mathrm{~L}$. Phytoplankton samples are immediately fixed with an alkaline solution of Lugol with about $5 \mathrm{ml}$ per 1L, and are stored in a dark and cool place $\left(4^{\circ} \mathrm{C}\right)$.

The technique used for sample preparation and phytoplankton identification and enumeration is that of Utermöhl (1958). This method consists of reading the sample under an inverted microscope (objective 40x, OPTIKA) with camera by counting the phytoplankton cells. The identification was carried out at the specific level or, in case of difficulty or uncertainty, at higher taxonomic level (genus, family or class) using different identification keys (Graham, 1942; Trégouboff, 1957; Taylor, 1976; Balech, 1988). The results were expressed in number of individuals per unit volume (ind/l).

\section{Temperature and salinity measurement}

These factors are the mean of the measurements taken each meter between $1 \mathrm{~m}$ and $20 \mathrm{~m}$ from the surface, using the Conductivity-Temperature-Depth (CTD) instrument set. Salinity is given by the PSU (Practical Salinity Unit) and temperature by degrees Celsius $\left({ }^{\circ} \mathrm{C}\right)$.

\section{Chlorophyll}

The MODIS AQUA (EOS PM-1) sensor is chosen to create the data base for this spectral resolution with 9 bands which are used to observe the color oceans.

Satellite images are downloaded every $5 \mathrm{~km}$ around each station to extract $\mathrm{Chl}$ values. The download was done on July 2017 by using the NASA Ocean Color website (http://reason.gsfc. nasa.gov/Giovan-ni) to access to database of GSFC (Goddard Space Flight Center) of NASA (National Aeronautics and Space Administration).

Images downloaded were then selected in clear sky and then treated on three stages:

- Calibration: it consist to transform reflectance values to numerical values by using algorithms integrated in ENVI software: OC3 algorithm for extracting chlorophyll concentrations.

- Geo-referencing: to have the punctual geographic coordinates according to the chosen stations by using projection system Geodesie WGS-84.

- Extraction of the information: by using the software ENVI 4.8, data were displayed by clicking on pixel under a clear sky. Displayed values were used to calculate the averages $(\mathrm{mg} / \mathrm{l})$.

\section{Numerical analysis}

Student test. The question is whether the means of the two groups are statistically significantly different when comparing the means. The calculation was done on Excel stat.

Shannon index. The Shannon diversity index (H) is commonly used to characterize species diversity in a community. Shannon's index accounts for both abundance and evenness of the species present.

It is given by:

$$
\mathrm{H}=-\sum_{\mathrm{i}=1}^{\mathrm{s}} \mathrm{p}_{\mathrm{i}} \ln \mathrm{p}_{\mathrm{i}} \text { with } \mathrm{Pi}=\frac{\mathrm{n}_{\mathrm{i}}}{\mathrm{N}}
$$

Chi-square test. This tests the hypothesis of independence of two categorical variables. If they

\begin{tabular}{|lcll|}
\hline $\mathrm{N}^{\circ}$ & Date & \multicolumn{1}{c|}{ Place } & \multicolumn{1}{c|}{ Reference } \\
\hline 22 & 2003 & Matanchen Bay, Nayarit, Mexican Pacific coast & Cortes et al. (2003) \\
23 & 2004 & Antwerp port, Belgium & Clark et al. (2004) \\
24 & Jan-06 & Karnataka old port, Arabian sea, India & Härnström et al. (2008) \\
25 & Autumn 2006 & Eastern Alboran Sea, Mediterranean sea & Fani et al. (2009) \\
& Jul 2017 & Western Algeria & Ali et al. (2020) \\
26 & 2007 & Baltic sea, Russia & Vershinin \& Orlova (2008) \\
27 & $2009-2012$ & Oslofjorden, Norway & Engesmo et al. (2018) \\
\hline
\end{tabular}

Table 1. First sightings of Fibrocapsa japonica in the worlds (the numbers correspond to figure 1). Modified from De Boer et al., 2004. 
share something in common, one variable influences the other.

$$
X_{C}^{2}=\sum_{i=1}^{K} \frac{(\mathrm{O} i-\mathrm{e} i)^{2}}{\mathrm{e} i}
$$

$\mathrm{c}=$ Degrees of freedom; $\mathrm{o}_{\mathrm{i}}=$ Observed value $(\mathrm{s}) ; \mathrm{e}_{\mathrm{i}}=$ Expected value (s).

\section{RESULTS}

The figure below represents the July 2017 mean Chl-a (mg/l) and measurement in-situ of temperature $\left({ }^{\circ} \mathrm{C}\right.$ ) and salinity (PSU) in stations for each region. The Chl-a concentration in AT varies between $0.15 \mathrm{mg} / 1$ and $0.19 \mathrm{mg} / \mathrm{l}$. Although the difference between the maximum and minimum values is minimal (0.04 difference), the positioning of the values at each station shows a decreasing gradient from coast to offshore. In the other hand, the chl-a concentration in the Arzew Gulf varies between $0.15 \mathrm{mg} / 1$ and $0.25 \mathrm{mg} / \mathrm{l}$.

The values positioned at each station show a particular pattern with increasing values from station 25 to station 18 , noting stability at stations 22 , 23 and 24 (Fig. 4). In addition, we note that the ra- dial with stations 18 to 21 is richer in Chl-a. The temperature varies between $22.7^{\circ} \mathrm{C}$ and $24.3^{\circ} \mathrm{C}$ at AT with an increasing temperature gradient from wide to offshore.

In the $\mathrm{AG}$ region, the temperature varies between $21.8^{\circ} \mathrm{C}$ and $23.5^{\circ} \mathrm{C}$ (this is the maximum at station 22). There is an increasing gradient on the radial 18-21 and a decreasing gradient on the radial 22-25. In general, AT is warmer than AG. Overall salinity remains stable at about 36.5 PSU at all stations in each region. We note the highest value (36.8 PSU) at station 22.

In Table 2, quantitative phytoplankton groups distribution per region can be seen.

AT: In all stations, diatoms are more abundant than dinoflagellates, except station 13 where dinoflagellates are clearly more dominant. Comparing this station with the nearest station (St 12), separated by a distance of $8.7 \mathrm{~km}$, an inversion in the distribution of the two groups is observed. Indeed, in station 12 diatoms are very abundant with 3630 ind/l against a low presence of dinoflagellates estimated at $120 \mathrm{ind} / 1$. Conversely, in station 13 dinoflagellates are more abundant with a contribution of $910 \mathrm{ind} / 1$ against $170 \mathrm{ind} / 1$ for diatoms.

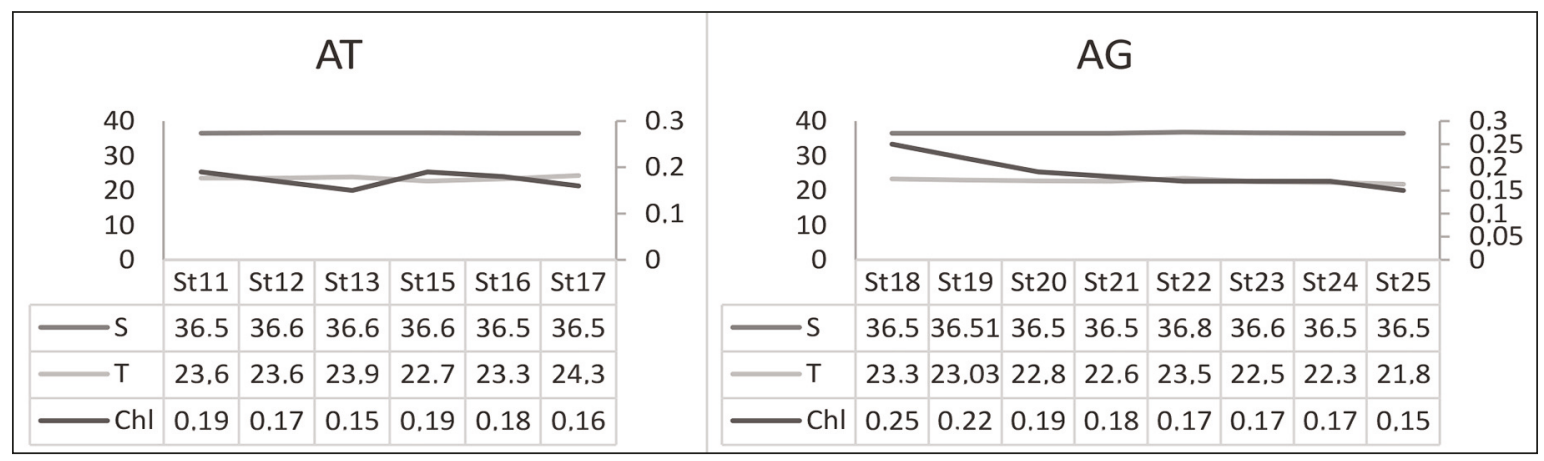

Figure 4. Chl-a (mg/l), temperature $\left({ }^{\circ} \mathrm{C}\right)$ and salinity (PSU) values in stations for each region.

\begin{tabular}{|llllllll|llllllll|}
\hline \multicolumn{1}{|c|}{ AT } & \multicolumn{11}{c|}{ AG } \\
\hline Stations & St11 & St12 & St13 & St15 & St16 & St17 & St18 & St19 & St20 & St21 & St22 & St23 & St24 & St25 \\
& & & & & & & & & & & \\
\hline Dinoflagellates & 110 & 120 & 910 & 120 & 310 & 350 & 160 & 260 & 270 & 70 & 290 & 10 & 200 & 510 \\
\hline Diatoms & 550 & 3630 & 170 & 1020 & 620 & 960 & 1130 & 150 & 170 & 120 & 2870 & 70 & 680 & 1190 \\
\hline
\end{tabular}


AG: Diatoms are more abundant in most of the stations except St19 and St20 where dinoflagellates are more abundant. This distribution follows the shape of the bay, forming an arc for each phytoplankton group (diatoms near the coast and dinoflagellates offshore).

The Student test shows that AT is richer in both dinoflagellates and diatoms then AG. However, this richness remains insignificant since the calculated $\mathrm{p}$-value is higher than the significance level threshold alpha $=0.05$, thus we cannot reject the null hypothesis $\mathrm{H}_{0}$ (Fig. 5).

Shannon Index application indicates that AG is slightly more diverse in dinoflagellates than the AT region, with $\mathrm{Ish}=3.6 \mathrm{ind} / \mathrm{bit}$ and $\mathrm{Ish}=3.1 \mathrm{ind} / \mathrm{bit}$ respectively. Nevertheless, the regularity index shows that this group is ecologically equitable in both regions with a homogeneous distribution and no specific dominance $(0.8<\mathrm{R}>0.9)$. Conversely, AT has a higher diatom diversity compared to AG, with respectively $\mathrm{Ish}=2.4 \mathrm{ind} / \mathrm{bit}$ and $\mathrm{Ish}=1.7$ ind/bit. The regularity index shows that AT is fair with a homogeneous distribution of diatoms $(\mathrm{R}=$ 0.7 , while $A G$ presents a moderately homogeneous distribution with $\mathrm{R}=0.5$.

The diversity index calculated per station of each group shows that station 13 is the most diverse with Ish $=2.97 \mathrm{ind} / \mathrm{bit}$, while station 22 is the least diverse with $\mathrm{Ish}=1.02 \mathrm{ind} / \mathrm{bit}$. The lowest regularity index $(\mathrm{R}=0.3)$ is noted in this station, indicating the presence of specific dominance. Indeed, the genus Chaetoceros contributes to more than $90 \%$ of dinoflagellates, i.e., 2600ind/1. On the other hand, the highest $\mathrm{R}$ index is noted in station $23(\mathrm{R}=1)$ fol-

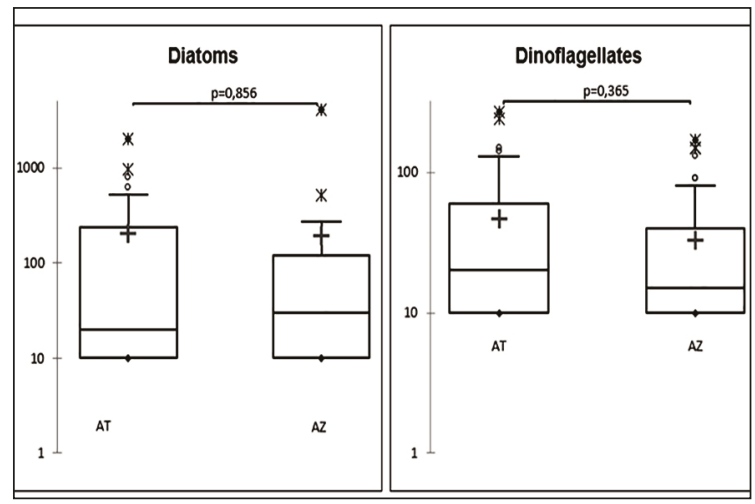

Figure 5. Box plot for diatoms and dinoflagellates. $\mathrm{H}_{0}$ : The difference between the averages $=0 . \mathrm{H}_{1}$ : The difference between the averages $\neq 0$. lowed by station 21 and 20 , with $\mathrm{R}=0.96$ and $\mathrm{R}=$ 0.71 respectively.

On the other hand, extreme values are given by certain genera of each group in each zone, which raises the question of whether or not the abundance of the groups is region-dependent, i.e., whether the region influences the abundance of phytoplankton groups. To answer this question the Chi-square test was applied.

Chi-square Test application. $\mathrm{H}_{0}$ : The distribution of phytoplankton groups does not depend on the region.

$\mathrm{H}_{1}$ : The distribution of phytoplankton groups depends on the region.

$X^{2}$ Calculated $=0.013$.

$X^{2}$ Table $=3.84$ for a d.d. $1=1$ and $\alpha=5 \%$

$X^{2} \mathrm{Cal}<<X^{2}$ tab.

$\mathrm{H}_{0}$ retained: the distribution of phytoplankton groups does not depend on the region, showing that they are homogeneously distributed in both regions.

The presence of dinoflagellates is $38 \%$ and $41 \%$ for AT and AG respectively, these values which are relatively close indicate that this group has a homogeneous distribution in these two sites. This is also observed for diatoms, with $10 \%$ in AT against $11 \%$ in $\mathrm{AG}$.

The overall quantitative analysis of the main phytoplankton groups shows that they are similarly distributed in the regions studied. This indicates that the characteristics of each area do not influence the abundance of dinoflagellates and diatoms.

A specific qualitative analysis of diatoms and dinoflagellates was necessary to determine the characteristic species in each area.

For the qualitative phytoplankton groups distribution per region, Table 3 shows that the AT and AG regions each have 13 genera of diatoms (without taking into account unidentified individuals), with the absence of the genera Cosinodiscus, Pinnularia and Pleurosigma in AG, and the absence of Detonula, Fragilaria and Thalassionema in AT. However, Chaetoceros are dominant in AG with 4170 ind/l compared to $1380 \mathrm{ind} / 1$ in AT. Furthermore, the genera Cylindrotheca, Dactyliosolen and Leptocylindrus are dominant in AT with $870 \mathrm{ind} / 1,1020 \mathrm{ind} / 1$ and $2370 \mathrm{ind} / 1$ respectively compared to $250 \mathrm{ind} / 1$, 480 ind/1 and $560 \mathrm{ind} / 1$ in AG. On the specific scale, AG has 26 species compared to 32 species in AT.

We report the presence of some harmful diatoms: Cylindrotheca closterium (produce mucilage: 


\begin{tabular}{|llll|lllll|}
\hline Genus & Species & AT & AG & Genus & Species & AT & AG \\
\hline Chaetoceros & ceratosporus & + & - & Nitzschia & seriata & + & - \\
Chaetoceros & convolutus & + & + & Nitzschia & sp & - & + \\
Chaetoceros & danicus & + & + & Pinnularia & spl & + & - \\
Chaetoceros & compressum & + & + & Pinnularia & sp2 & + & - \\
Chaetoceros & didymus & + & + & Pinnularia & sp3 & + & - \\
Chaetoceros & sp2 & + & - & Pinnularia & sp4 & + & - \\
Chaetoceros & sp3 & - & + & Gyrosigma & sp & + & - \\
Coscinodiscus & sp & + & - & Pseudo-nitzschia & seriata & + & + \\
Cylindrotheca & closterium & + & + & Pseudo-nitzschia & delicatissima & - & + \\
Dactyliosolen & fragilimus & + & + & Rhizosolenia & spl & + & + \\
Dactyliosolen & spl 1 & + & - & Rhizosolenia & styliformis & + & + \\
Dactyliosolen & sp2 & - & + & Rhizosolenia & sp3 & + & + \\
Dactyliosolen & sp3 & - & + & Rhizosolenia & setigera & - & + \\
Detonula & sp & - & + & Thalassionema & nitzschioides & - & + \\
Achnanthes & coarctata & - & + & Unidentified & spl & + & - \\
Guinaridia & striata & - & + & Unidentified & sp2 & + & - \\
Leptocylindrus & minimus & + & + & Unidentified & sp3 & + & - \\
Leptocylindrus & danicus & + & + & Unidentified & sp4 & + & - \\
Leptocylindrus & sp & + & - & Unidentified & sp5 & - & + \\
Licmophora & abbreviata & + & + & Unidentified & sp6 & - & + \\
Navicula & sp & + & + & Unidentified & sp7 & - & + \\
Nitzschia & amphibia & + & + & Unidentified & sp8 & - & + \\
Nitzschia & closterium & + & - & Unidentified & sp9 & - & + \\
Nitzschia & longissima & + & + & Unidentified & splo & - & + \\
\hline Unidentified : isolated cells $<20$ & ind/1 & & & & + \\
\hline
\end{tabular}

Table 3. Diatoms population in AT and AG regions. Unidentified: isolated cells $<20$ ind/l.

Kraberg et al., 2010), Dactyliosolen fragilimus (clog fills of benthic shelfish: Lorrain et al., 2000) Guinaridia striata (impact copepod reduction: Wichard et al., 2008), Pseudo-nitzschia seriata and $P$. delicatissima (amnesic shellfish poison: Hasle \& Syvertsen, 1997), and Rhizosolenia setigera (anoxic conditions, mortalities of marine organisms).

We notice that the sum of these harmful diatoms in the AT region exceeds that of the AG region, i.e., $2750 \mathrm{ind} / \mathrm{l}$ against $1090 \mathrm{ind} / \mathrm{l}$, respectively.
We note the presence of 21 genera of dinoflagellates distributed into 20 genera in AG and 14 genera in AT (without taking into account unidentified individuals), with the absence of the genera Alexandrium, Fibrocapsa, Gonyaulax, Gonyostomum, Ornithocercus, Oxytoxum and Pyrodinium in AT. Only the genus Scripsiella is absent in AG (Table 4).

There is no dominance of genus or species of dinoflagellates in either region. The highest value is 


\begin{tabular}{|c|c|c|c|c|c|c|c|}
\hline Genus & Species & AT & $\mathrm{AG}$ & Genus & Species & AT & $\mathrm{AG}$ \\
\hline Alexandrium & $s p$ & - & + & Protoperidinium & spl & + & - \\
\hline Amphidoma & caudata & + & + & Protoperidinium & $s p 2$ & + & - \\
\hline Amphidoma & languida & + & + & Protoperidinium & $s p 3$ & + & - \\
\hline Azadinium & sinosum & + & + & Protoperidinium & $s p 4$ & - & + \\
\hline Ceratium & arcuatum & + & + & Protoperidinium & steinii & + & + \\
\hline Ceratium & candelabrum & + & - & Protoperidinium & diabolus & + & + \\
\hline Ceratium & extensum & + & - & Protoperidinium & tenuissium & - & + \\
\hline Ceratium & furca & + & + & Protoperidinium & sournai & - & + \\
\hline Ceratium & fusus & + & + & Protoperidinium & spl & + & - \\
\hline Ceratium & shrankii & - & + & Protoperidinium & $s p 2$ & + & - \\
\hline Ceratium & tripos & + & + & Protoperidinium & $s p 3$ & + & - \\
\hline Ceratium & horridum & + & - & Protoperidinium & $s p 4$ & + & + \\
\hline Ceratium & longipes & + & - & Protoperidinium & sp5 5 & + & + \\
\hline Ceratium & macroceros & - & + & Protoperidinium & sp6 & - & + \\
\hline Ceratium & massilens & - & + & Protoperidinium & sp 7 & - & + \\
\hline Ceratocorys & horrida & + & + & Protoperidinium & $\operatorname{sp} 8$ & - & + \\
\hline Dinophysis & caudata & + & + & Protoperidinium & $s p 9$ & - & + \\
\hline Dinophysis & $s p$ & - & + & Protoperidinium & sp10 & - & + \\
\hline Euglena & viridis & + & + & Pyrodinium & $s p$ & + & - \\
\hline Euglena & gracilis & + & - & Pyrophacus & steinii & - & + \\
\hline Fibrocapsa & japonica & - & + & Pyrophacus & vancampoae & + & - \\
\hline Gonyaulax & $s p$ & - & + & Pyrophacus & $s p$ & + & - \\
\hline Gymnodinium & $s p$ & + & - & Pyrophacus & hologium & + & - \\
\hline Gymnodinium & fusus & - & + & Scripsiella & trochoidea & - & + \\
\hline Gyrodinium & $s p$ & + & + & Unidentified & spl & - & + \\
\hline Gyrodinium & $s p$ & - & + & Unidentified & $s p 2$ & + & - \\
\hline Gyrodinium & $s p$ & - & + & Unidentified & $s p 3$ & + & - \\
\hline Gyrodinium & $s p$ & - & + & Unidentified & $s p 4$ & + & - \\
\hline Noctulica & scintillans & + & + & Unidentified & $\operatorname{sp} 5$ & + & - \\
\hline Ornithocercus & magnificus & - & + & Unidentified & sp6 & - & + \\
\hline Oxytoxum & spl & - & + & Unidentified & $s p 7$ & - & + \\
\hline Oxytoxum & sp2 & - & + & Unidentified & $\operatorname{sp} 8$ & - & + \\
\hline Polykrikos & kofoidii & + & + & Unidentified & sp9 & - & + \\
\hline Prorocentrum & compressum & + & + & Unidentified & sp10 & - & + \\
\hline Prorocentrum & spl & + & - & Unidentified & spl1 & - & + \\
\hline Prorocentrum & sp2 & + & - & Unidentified & spl2 & - & + \\
\hline Prorocentrum & lima & + & - & Unidentified & sp13 & - & + \\
\hline Prorocentrum & micans & - & + & Unidentified & spl4 & - & + \\
\hline Prorocentrum & minimum & - & + & Unidentified & sp15 & - & + \\
\hline Prorocentrum & tristinum & - & + & Unidentified & spl6 & - & + \\
\hline
\end{tabular}

Table 4. Dinoflagellates population in AT and AG regions. Unidentified: isolated cells $<20$ ind/l. 
attributed to the genus Ceratium with $640 \mathrm{ind} / 1$ at AT and 250 ind $/ 1$ at $\mathrm{AG}$.

As opposed to what has been noticed for toxic diatoms, the sum of toxic dinoflagellates in AG is higher than the sum in AT, respectively $860 \mathrm{ind} / 1$ versus $330 \mathrm{ind} / 1$.

As previously mentioned, $F$. japonica is absent in AT and present AG, precisely in station 22 at 110 ind/l. The cells were rounded to oval in size $23 \mu \mathrm{m} \times$ $32.8 \mu \mathrm{m}$ with multiple chloroplasts and mucocysts located in the posterior end (Fig. 6). The anterior (beating) and posterior (trailing) flagella are not apparent.

\section{DISCUSSION}

The chlorophyll and temperature values positioned at each station show that they vary inversely in the AT region (normal conditions). Indeed, there was a decreasing coast-offshore gradient of chlorophyll and an increasing gradient of temperature. While in the AG region chlorophyll and temperature vary simultaneously, noting a decreasing gradient for both chlorophyll and temperature on the 18-21 radial and an increasing gradient on the 2522 radial, resulting in a continuous decreasing gradient from station 11 to station 25 (Fig. 7). This shape reminds us of the coastal eddies described by Millot et al. (1999) in the Algerian basin. Indeed, it can be said that the coastal gyre also exists inside the Arzew gulf and is responsible for the distribution of $\mathrm{T}^{\circ} \mathrm{C}$ and $\mathrm{Chl}$ in $\mathrm{AG}$ region.

We notice that the AT region is warmer than the AG region, yet AT is closer to the cold Atlantic waters entering through the Gibraltar and bordering the Algerian west coast. It is assumed that the low temperatures recorded in the Arzew gulf indicate an upwelling of coastal water.

Salinity remains relatively stable with a value of 35.5 PSU. This value correspond to the Atlantic waters that enter via Gibraltar and that border the Algerian coast (Millot et al., 1999). Nevertheless, the highest value of 36.8 PSU was recorded at station 22 where $F$. japonica was reported. On the other hand, Fani et al. (2014) found the highest abundances of $F$. japonica were recorded under salinity conditions of 36.6 PSU to 37.7 PSU.

The high presence of diatoms compared to dinoflagellates in the two regions AT and AG was also noted in the Alboran Sea by Boudjnah et al. (2019).
Nevertheless, we note that both AT and AG regions are poor in phytoplankton density, with $8870 \mathrm{ind} / 1$ at AT and 8150 ind/1 at AG. This remark was also given by Boudjnah et al. (2019) where the lowest density of the whole Algerian coast was found in the Alboran Sea, precisely in Ain Temouchent (AT region) with 740 ind/l). Fani et al. (2014) was able to detect the presence of $F$. japonica between $1^{\circ} \mathrm{W}$ and $1^{\circ} \mathrm{E}$ and $36^{\circ}$ and $37^{\circ} \mathrm{N}$. This zone corresponds to a cyclonic eddy, which confirms its confinement in cyclonic waters only.

This zone is located off the Mediterranean Sea between Algeria and Spain, corresponding exactly to the offshore between Arzew and Cartagena. The highest cell abundance was noted at stations south of this area, near Algerian waters. In our study, $F$. japonica was detected at station 22. This station is located south of the gyre where $F$. japonica was detected by Fani et al. (2014). Nevertheless, we found a low abundance of this cell at $110 \mathrm{ind} / 1$, which could be explained by the fact that Station 22 is located near and outside the hurricane zone. Furthermore, this species was not detected between $2^{\circ} \mathrm{W}$ and $7^{\circ} \mathrm{W}$ and $35^{\circ}$ and $37^{\circ} \mathrm{N}$. This zone corresponds to the western Mediterranean, from the open sea of Almeria-Oran to the Spanish Atlantic coast, including the AT region (absence of $F$. japonica in our study). Thus, the result of our study can be said to be consistent with the results of Fani et al. (2014).

Regarding the local source of $F$. japonica, Fani et al. (2014) suggests that cells of this species may have been captured in a coastal assemblage along the Spanish coast, trapped in the Almeria-Oran jet

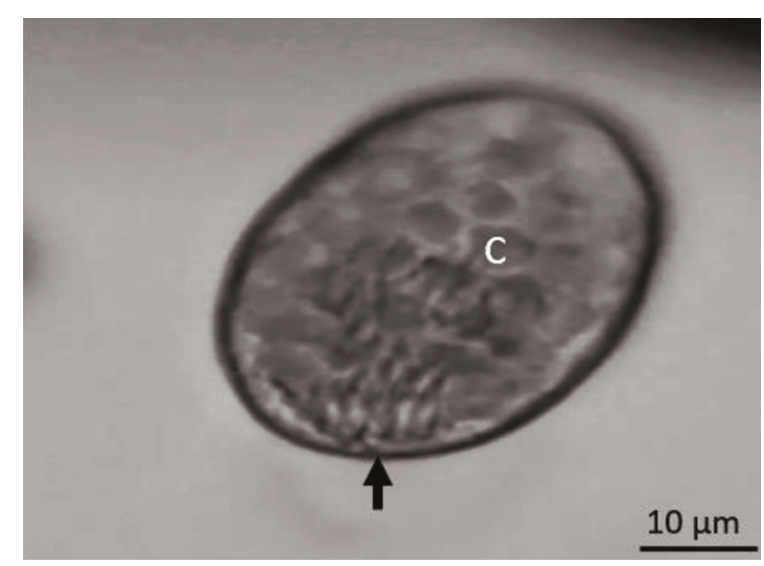

Figure 6. Picture of Fibrocapsa japonica with chloroplast (c) and mucocysts (arrow). 
and eventually drain offshore in cyclonic waters. Moreover, the map established by Bouda et al. (2015) of the risk level introduction species in Arzew port shows that medium and high risk category ports are located in the western Mediterranean and on the European Atlantic coast (Fig. 8). Therefore, we assume that the presence of $F$. japonica across the port of Arzew and Bethioua is of anthropogenic origin from ballast water sources from $\mathrm{Eu}$ ropean ports (France, Spain, Italy and Germany).

\section{CONCLUSIONS}

The main biotic and abiotic factors (temperature, salinity and chlorophyll) has shown that the two regions $\mathrm{AT}$ and $\mathrm{AG}$ generally have the same characteristics. There are, however, some small differences in values and distributions due to the different topography of the study areas and exposure to marine currents. Indeed, AT receives incoming Atlantic waters through the Strait of Gibraltar. The AG region is a sheltered gulf, the current passes outside creating an eddy inside the gult. This eddy has a major role in the distribution of the abovementioned factors.

The study of the phythoplankton population showed a homogeneous quantitative distribution between the AT and AG regions. Diatoms and dinoflagellates have an equal density in both regions. nevertheless diatoms are more abundant in each region, and according to the results of our study and the results of the study of Boudjnah et al. (2019) it can be concluded that the dominance of diatoms

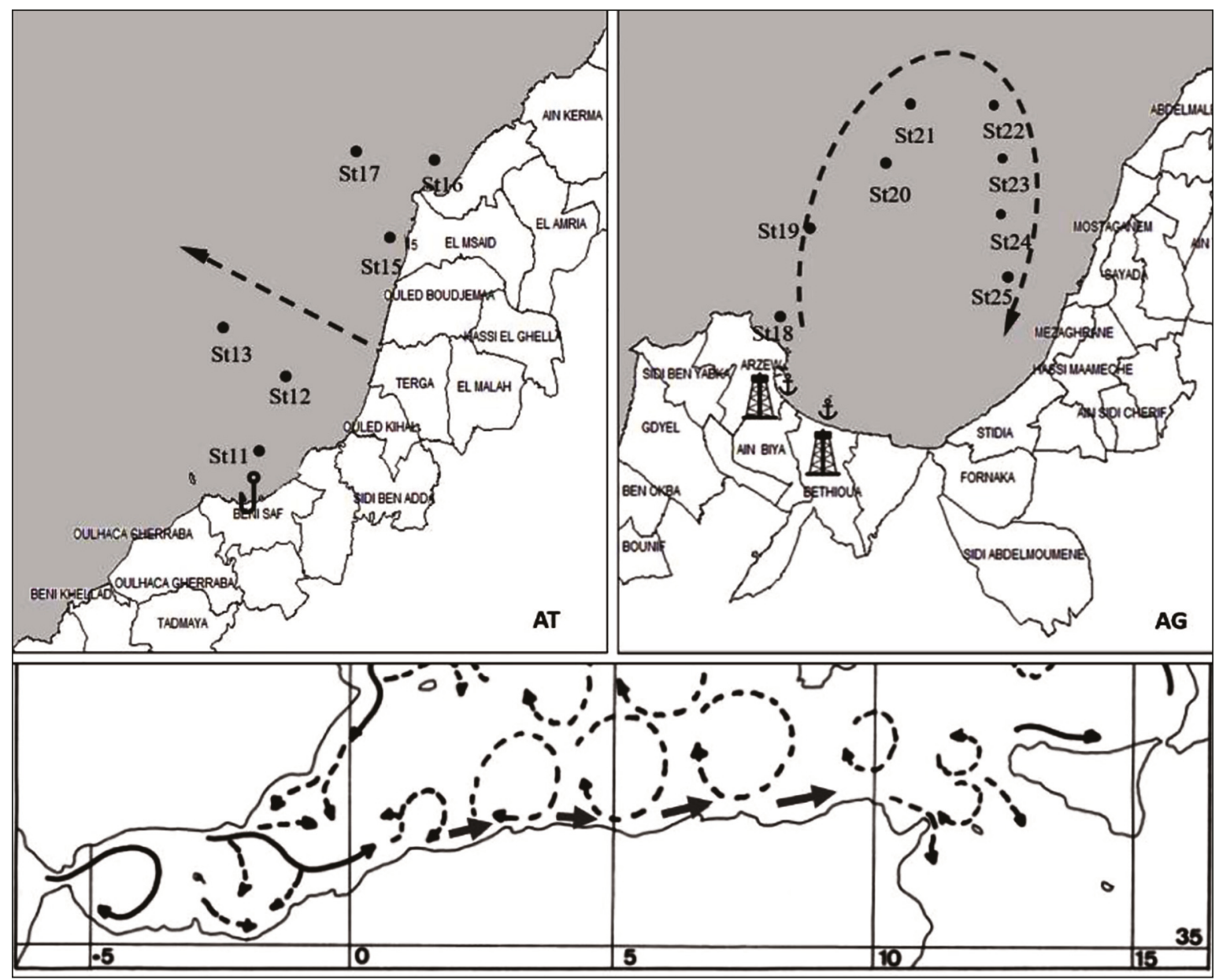

Figure 7. Thermal and chlorophyll gradient. Bottom: map of the modified Atlantic water circulation (MAW), and the Algerian current (modified from Millot et al., 1999). 


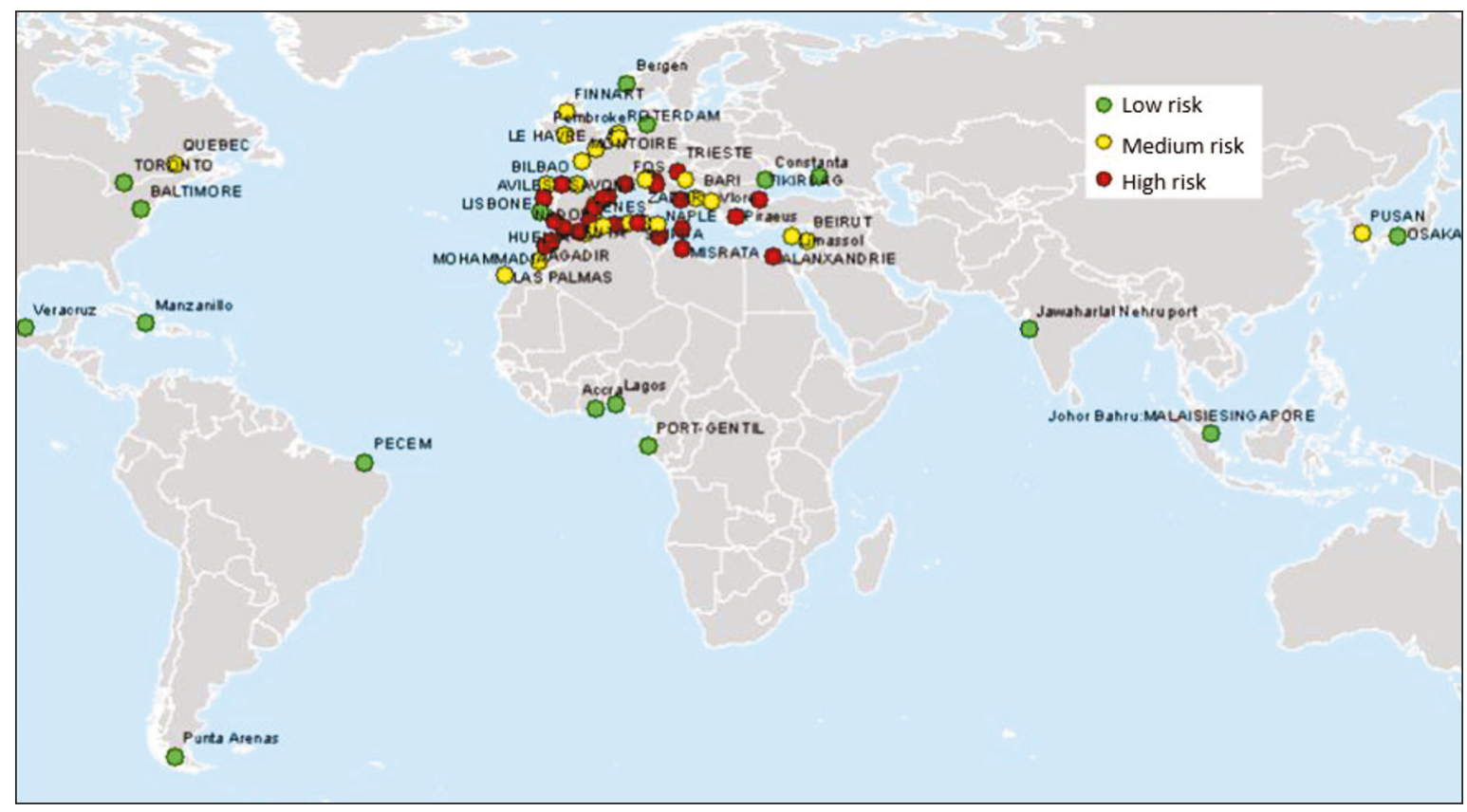

Figure 8. Map illustrating spatial patterns of all donor ports in the world, according of their category of risk (2014) (Bouda et al., 2015).

over dinoflagellates is a characteristic of the Alboran Sea.

On the other hand, there was a qualitative difference. The most important and interesting result is the presence of the non-indigenous species F. japonica in Arzew Gulf (AG) and its absence in the reference area AT. We cannot really conclude the source of the presence of this species on the west Algerian coast, but it is quite possible that it is a source of ballast water, since it was found across the port of transport of hydrocarbons using ballast water for this purpose (Arzew and Bethioua), and it has not been detected in the AT zone, which has only a small fishing port.

To confirm the source of the presence of $F$. japonica in Arzew gulf, it would be best to carry out a phytoplankton analysis of seawater pumped by ships from suspected donor ports in order to identify F. japonica in this ballast water. It is also interesting to compare the species already present in the Arzew gulf with species of strains from the suspect regions in order to know their origin.

We notice that this species is no longer trapped in the eddy and is moving closer to the coast. However, despite its low abundance in the Gulf of Arzew, this species is still reported harmful, we fear that it may be transported by the Algerian current to other areas of the Algerian coast, including fisheries and aquaculture production areas.

Our study is part of the prevention and conservation framework, and according to our conclusions and hypothesis, it is absolutely necessary to adopt national regulations and action programmes in order to prevent the introduction of non-indigenous species, particularly harmful ones, and to preserve local biodiversity.

\section{REFERENCES}

Balech E., 1988. Los dinoflagelados del Atl'antico Sudoccidental. Publicaci'ones Especiales Instituto Espanol de Oceanografia 1: 1-310.

Bensari B., Bahbah L., Lounaouci A., Fahci S.E., Bouda A. \& Bachari N.E.I., 2020. First records of non-indigenous species in port of Arzew (Algeria: southwestern Mediterranean). Mediterranean Marine Science, 21: 393-399. https://doi.org/10.12681/ mms. 21927

Bouda A., Bachari N.E.I., Bahmed L. \& Boubenia R., 2015. Design of a risk assessment methodology for the introduction of invasive species from ship ballast 
waters The case of Arzew port. Management of Environmental Quality, 27: 474-490. http://dx.doi.org/ 10.1108/MEQ-02-2015-0023

Boudjnah M., Mokrane Z. \& Soualili D., 2019. Diversity of Phytoplanktonic populations along the Algerian coastline. Biodiversity Journal, 10: 81-92. https:// doi.org/10.31396/biodiv.jour.2019.10.2.81.92

Cortés-Lara M.C., Cortés-Altamirano R. \& Cupul-Magaña A.L., 2003. First record of Fibrocapsa japonica in Matanchen Bay, Nayarit, Mexican Pacific coast. Harmful Algae News, 24: 3-4.

de Boer M.K., Tyl M.R., Vrieling E.G. \& van Rijssel, M., 2004. Effects of salinity and nutrient conditions on growth and haemolytic activity of Fibrocapsa japonica (Raphidophyceae). Aquatic Microbial Ecology, 37: 171-181. https://doi.org/10.3354/ame037171

de Boer M.K., Tyl M.R., Vrieling E.G. \& van Rijssel M., 2005. Temperature responses of three Fibrocapsa japonica strains (Raphidophyceae) from different climate regions. Journal of Plankton Research, 27: 47 60. https://doi.org/10.1093/plankt/fbh149

Diz A.P. \& Presa P., 2008. Regional patterns of microsatellite variation in Mytilus galloprovincialis from the Iberian Peninsula. Marine Biology, 154: 277-286. http://dx.doi.org/10.1007/s00227-008-0921 $-3$

Engesmo A., Strand D., Gran-Stadniczenko S., Edvardsen B., Medlin L.K. \& Eikrem W., 2018. Development of a qPCR assay to detect and quantify ichthyotoxic flagellates along the Norwegian coast, and the first Norwegian record of Fibrocapsa japonica (Raphidophyceae). Harmful Algae, 75: 105-117.

Fani F., Nuccio C., Lazzara L., Ciofi C. \& Natali C., 2009. First observation of Fibrocapsa japonica (Raphidophyceae) in a cyclonic eddy in the eastern Alboran Sea (western Mediterranean Sea). Biologia Marina Mediterranea, 16: 382-383.

Fani, F., Nuccio, C., Lazzara, L., Massi, L., Battocchi, C., \& Penna, A., 2014. Fibrocapsa japonica (Raphidophyceae) occurrence and ecological features within the phytoplankton assemblage of a cyclonic eddy, offshore the Eastern Alboran Sea. Mediterranean Marine Science, 15: 250-262.

Fu M., Koulman A., Van Rijssel M. et al., 2004. Chemical characterisation of three haemolytic compounds from the microalgal species Fibrocapsa japonica (Raphidophyceae). Toxicon, 43: 355-363. https://doi. org/10.1016/j.toxicon.2003.09.012

García-Merchán V.H., Robainas-Barcia A., Abelló P., Macpherson E., Palero F., García-Rodríguez M., Gil de Sola L. \& Pascual M., 2012. Phylogeographic patterns of decapod crustaceans at the Atlantic-Mediterranean transition. Molecular Phylogenetics and Evolution 62: 664-672. https://doi.org/10.1016/j. ympev.2011.11.009
Graham H., 1942. Studies in the Morphology, Taxonomy and Ecology of Ihe Peridinales. Vol. 542. Carnegie Institution of Washington. Graham, H., \& Bronikovsky, N., 1944. The genus Ceratium in the Pacific and North Atlantic oceans. Vol. 565. Carnegie Institution of Washington.

Grimes S., Benabdi M., Babali N., Refes W., Boudjellal-kaidi N. \& Seridi H., 2018. Biodiversity changes along the Algerian coast (Southwest Mediterranean basin): from 1834 to 2017: A first assessment of introduced species. Mediterranean Marine Science, 19: 156-179. http://dx.doi.org/10.12681/mms.13 824

Härnström K., Karunasagar I. \& Godhe A., 2009. Phytoplankton species assemblages and their relationship to hydrographic factors - a study at the old port in Mangalore, coastal Arabian Sea. Indian Journal of Marine Sciences, 38: 224-234.

Hasle G.R. \& Syvertsen E.E., 1997. Marine diatoms. In: Tomas C.R. (Ed.), Identifying Marine Phytoplankton. Academic Press, San Diego, 858 pp.

Iwasaki H., 1971. Studies on the red tide flagellates. VI. On Eutreptiella sp. and Exuviaella sp. appeared in Bingo-Nada, the Seto Inland Sea, in 1970. Journal of the Oceanographical Society of Japan, 27: 152 157.

Khan S., Arakawa O. \& Onoue, Y., 1996a. Growth characteristics of a neurotoxin-producing chloromonad Fibrocapsa japonica (Raphidophyceae). Journal of the World Aquaculture Society, 27: 247-253. https://doi.org/10.1111/j.1749-7345. 1996.tb00606.x

Khan S., Arakawa O. \& Onoue Y., 1996b. Neurotoxin production by a chloromonad Fibrocapsa japonica (Raphidophyceae). Journal of the World Aquaculture Society, 27: 254-263. https://doi.org/10.1111/j.1749_ 7345.1996.tb00607.x

Kooistra W.H.C.F., de Boer M.K., Vrieling E.G., Connell L.B. \& Gieskes W.W.C., 2001. Variation along ITS markers across strains of Fibrocapsa japonica (Raphidophyceae) suggests hybridisation events and recent range expansion. Journal of Sea Research, 46: 213-222.

Kraberg A.C., Baumann M.E.M. \& Durselen C.-D., 2010. Coastal Phytoplankton: Photo Guide for Northern European Seas. Verlag Dr. Friedrich Pfeil, Munchen, 204 pp.

Hiromi J., Imanishi D. \& Kadota S., 1995. Effect of Cylindrotheca closterium (Bacillariophyceae) on the growth of red-tide raphidophycean flagellate Heterosigma akashiwo. Bulletin of the College of Agriculture and Veterinary Medicine, Nihon University, 52: $122-125$.

Lorrain A., Paulet Y.M., Chauvaud L., Savoye N., Nezan, E. \& Guerin L., 2000. Growth anomalies in Pecten maximus from coastal waters (Bay of Brest, France): 
relationship with diatom blooms. Journal of Marine Biological Association of the United Kingdom, 80: 667-673.

Millot C., 1999. Circulation in the western Mediterranean Sea. Journal of Marine Systems, 20: 423-442.

Okaichi T., 1989. Red-tides problems in the Seto Inland sea. Japan, p p. 137-142. In: Red Tides: Biology, Environmental Science and Toxicology.

Pascual M., Rives B., Schunter C. \& Macpherson E., 2017. Impact of life history traits on gene flow: A multispecies systematic review across oceanographic barriers in the Mediterranean Sea. PLOS ONE, 12(5), e0176419. http://dx.doi.org/10.1371/journal.pone. 0176419.

Riesgo A., Pérez-Portela R., Pita L., Blasco G., Erwin P. M. \& López-Legentil S., 2016. Population structure and connectivity in the Mediterranean sponge Ircinia fasciculata are affected by mass mortalities and hybridization. Heredity, 117: 427-439. http://dx.doi. org/10.1038/hdy.2016.41

Taylor E.J.R., 1976. Dinoflagellates from the international Indian Ocean expedition. A report on material collected by the "Anton Bruun" 1963-64, 132, Stuttgart, $234 \mathrm{pp}$.

Toriumi S. \&Takano H., 1973. Fibrocapsa, a new genus in Chloromonadophyceae from Atsumi Bay, Japan. Bulletin of Tokai Regional Fisheries Research Laboratory, 76: 25-35.

Trégouboff G. \& Rose M., 1957. Manuel de planctonologie méditerranéenne texto (N.574.922 T7).

Utermöhl H., 1958. Zur Vervollkommnung der quantitativen. Phytoplankton-Methodik. Verhandlungen der Internationalen Vereinigung für Theoretische und Angewandte Limnologie, 9: 1-38.

Vershinin A.O. \& Orlova T.Y., 2008. Toxic and harmful algae in the coastal waters of Russia. Oceanology, 48: 524-537.

Wichard T., Poulet S.A., Boulesteix A.L., Ledoux J.B., Lebreton B., Marchetti J. \& Pohnert G., 2008. Influence of diatoms on copepod reproduction. II. Uncorrelated effects of diatom-derived $\alpha, \beta, \gamma$, $\delta$-unsaturated aldehydes and polyunsaturated fatty acids on Calanus helgolandicus in the field. Progress in Oceanography, 77: 30-44. 
. 